\title{
Listeria meningitis complicating infliximab treatment for Crohn's disease
}

\author{
Geoffrey Williams MD, Asad A Khan MD FRCPC, Franzjosef Schweiger MD FRCPC FACP FACC
}

G Williams, AA Khan, F Schweiger. Listeria meningitis complicating infliximab treatment for Crohn's Disease. Can J Infect Dis Med Microbiol 2005;16(5):289-292.

Infliximab, a monoclonal antibody directed against tumour necrosis factor-alpha, is an effective therapy for Crohn's disease. Though uncommon, serious opportunistic infections, including reactivation of tuberculosis, have occurred in patients after infliximab administration.

Meningitis caused by Listeria monocytogenes developed in a 37-yearold man six days after the second infusion of infliximab. The patient, who also was treated with azathioprine and corticosteroids, had an uneventful recovery after a course of antibiotics. Several other recent reports have implicated infliximab therapy in the development of severe Listeria infections, particularly meningitis and sepsis. With the increasing use of tumour necrosis factor-alpha-neutralizing agents, clinicians should be aware of the risk of opportunistic infections caused by $L$ monocytogenes in patients with Crohn's disease following infliximab treatment.

\section{Traitement de la maladie de Crohn par inflix- imab compliqué d'une méningite à Listeria}

L'infliximab, un anticorps monoclonal dirigé contre le facteur de nécrose tumorale alpha, est un traitement efficace de la maladie de Crohn. Bien que rares, des infections opportunistes, dont la réactivation de la tuberculose, sont survenues chez certains patients à la suite d'un traitement par infliximab.

Ainsi, une méningite à Listeria monocytogenes s'est développée chez un homme de 37 ans, six jours après sa deuxième perfusion d'infliximab. Le patient, qui prenait également de l'azathioprine et des corticostéroïdes, s'est rétabli sans complications après une antibiothérapie. Plusieurs autres rapports ont récemment mentionné le rôle de l'infliximab dans le développement de graves infections à Listeria, surtout la méningite et la septicémie. Compte tenu de l'emploi de plus en plus répandu d'agents neutralisant le facteur de nécrose tumorale alpha, les médecins doivent être au courant des risques d'infections opportunistes à $L$ monocytogenes chez les patients atteints de maladie de Crohn après un traitement par infliximab.

Key Words: Crohn's disease; Infliximab; Listeria meningitis

Tnfliximab, a human/murine chimeric monoclonal antibody directed against tumour necrosis factor-alpha (TNF- $\alpha$ ), is a new and effective therapy for active Crohn's disease (CD), and chronic refractory and fistulizing disease (1-3).

Early studies reported low rates of adverse effects in patients treated with infliximab for CD (4). However, recent studies point toward infrequent but potentially serious events, including opportunistic infections and sepsis $(3,5,6)$.

Listeria monocytogenes, a Gram-positive intracellular bacillus, can be isolated from well water, sewage, and the intestinal tract of humans and animals. This organism can cause sporadic or epidemic infection, and can be found in the feces of $1 \%$ to $5 \%$ of asymptomatic, healthy adults. Transmission occurs via contaminated food such as unpasteurized milk, soft cheeses, cole slaw, undercooked meats and raw vegetables (7). Human disease generally occurs at the extremes of life (younger than two months or older than 60 years of age) or in the setting of pregnancy or immunosuppression, and manifests itself as a systemic illness associated with bacteremia, sepsis, meningitis and other systemic complications (8). Case mortality has been estimated to be $27 \%$, and many patients with central nervous system involvement are left with neurological sequelae (8).

We describe a patient with severe Crohn's colitis who developed listeria meningitis six days after his second infusion of infliximab. A review of the literature suggests that this particular complication after anti-TNF- $\alpha$ administration may be seen increasingly in clinical practice with the rising use of this medication.

\section{CASE PRESENTATION}

A 37-year-old man presented with a two-week history of nausea, vomiting, abdominal cramps and diarrhea associated with some blood. He reported weight loss $(4 \mathrm{~kg})$, fever and chills over the preceding 10 days. On examination, he was dehydrated, hypotensive and had diffuse abdominal tenderness.

Department of Internal Medicine, South-East Health Care Authority, The Moncton Hospital, Moncton, New Brunswick

Correspondence: Dr Franzjosef Schweiger, 100 Arden Street, Suite 405, Moncton, New Brunswick E1C 4B7.

Telephone 506-858-8441,fax 506-858-0859, e-mail schweigr@nb.sympatico.ca

Received for publication December 7, 2004. Accepted March 16, 2005 
TABLE1

Listeria infections in Crohn's disease patients treated with infliximab

\begin{tabular}{|c|c|c|c|c|c|}
\hline $\begin{array}{l}\text { Agel } \\
\text { sex }\end{array}$ & Doses & $\begin{array}{l}\text { Concomitant } \\
\text { drugs }\end{array}$ & $\begin{array}{l}\text { Type of } \\
\text { infection }\end{array}$ & Outcome & Authors \\
\hline $67 / \mathrm{M}$ & 3 & $\begin{array}{l}\text { Prednisone, } \\
\text { azathioprine, } \\
\text { 5-ASA }\end{array}$ & Blood & Recovered & $\begin{array}{l}\text { Morelli } \\
\text { et al (17) }\end{array}$ \\
\hline $17 / F$ & 1 & $\begin{array}{c}\text { Methylprednisolone, } \\
\text { 6-MP, 5-ASA }\end{array}$ & $\begin{array}{l}\text { Blood, } \\
\text { meningitis }\end{array}$ & Recovered & $\begin{array}{l}\text { Kamath } \\
\text { et al (19) }\end{array}$ \\
\hline $64 / F$ & 1 & $\begin{array}{l}\text { Prednisone, } \\
\text { 6-MP, } \\
\text { glyburide }\end{array}$ & Blood & Recovered & $\begin{array}{l}\text { Slifman } \\
\text { et al (18) }\end{array}$ \\
\hline $39 / F$ & 3 & $\begin{array}{l}\text { Prednisone, } \\
\text { 6-MP, 5-ASA }\end{array}$ & $\begin{array}{l}\text { Blood, } \\
\text { meningitis }\end{array}$ & $\begin{array}{l}\text { Recovered, } \\
\text { paralysis of } \\
\text { one eye }\end{array}$ & $\begin{array}{l}\text { Slifman } \\
\text { et al (18) }\end{array}$ \\
\hline 20/M & 1 & $\begin{array}{l}\text { Methylprednisolone, } \\
\text { azathioprine, } \\
\text { metronidazole, } \\
\text { 5-ASA }\end{array}$ & Meningitis & Death & $\begin{array}{l}\text { Slifman } \\
\text { et al (18) }\end{array}$ \\
\hline $48 / \mathrm{M}$ & 1 & None & $\begin{array}{l}\text { Blood, } \\
\text { splenic } \\
\text { abscess }\end{array}$ & Recovered & $\begin{array}{l}\text { Tweezer- } \\
\text { Zaks } \\
\text { et al (21) }\end{array}$ \\
\hline $41 / \mathrm{F}$ & 1 & $\begin{array}{l}\text { Prednisone, } \\
\text { azathioprine }\end{array}$ & Meningitis & Recovered & $\begin{array}{l}\text { Joosten } \\
\text { et al (20) }\end{array}$ \\
\hline $\begin{array}{l}\text { Not } \\
\text { known }\end{array}$ & $\begin{array}{l}\text { Not } \\
\text { known }\end{array}$ & $\begin{array}{l}\text { Not } \\
\text { known }\end{array}$ & Meningitis & Recovered & $\begin{array}{l}\text { Ljung } \\
\text { et al (6) }\end{array}$ \\
\hline
\end{tabular}

Investigations revealed the presence of Bacteroides fragilis bacteremia, but stool testing for bacterial pathogens, Clostridium difficile toxins and parasites was negative. Flexible sigmoidoscopy showed severe colitis with deep ulcerations in the sigmoid colon consistent with CD. He improved with intravenous fluids, broad-spectrum antibiotics and corticosteroids, and was discharged after three weeks in hospital.

One week later, he redeveloped diarrhea, cramps and blood in the stool, which required rehospitalization. Intravenous methylprednisolone, azathioprine and 5-aminosalicylic acid (5-ASA) were administered. With no improvement after three days, $5 \mathrm{mg} / \mathrm{kg}$ of infliximab was infused, which resulted in remarkable improvement of his symptoms and early discharge.

The patient received a second infusion of infliximab $(5 \mathrm{mg} / \mathrm{kg}$ ) one month after the first infusion as an outpatient. At that time, he also was on a daily dose of prednisone $(35 \mathrm{mg}), 5$-ASA $(4 \mathrm{~g})$ and azathioprine $(1.8 \mathrm{mg} / \mathrm{kg})$. Clinically, the patient felt improved and had two to three semiformed bowel movements per day.

Six days later, he presented with fever, tachycardia, diaphoresis and confusion. His temperature was $40^{\circ} \mathrm{C}$. There were no signs of meningeal irritation and no focal neurological findings. Laboratory data showed a white blood cell count of $14.5 \times 10^{9} / \mathrm{L}$, a hemoglobin level of $125 \mathrm{~g} / \mathrm{L}$, a platelet count of $501,000 \times 10^{9} / \mathrm{L}$ and an erythrocyte sedimentation rate of $84 \mathrm{~mm} / \mathrm{h}$. Cranial computerized tomography was normal. Lumbar puncture yielded cloudy cerebrospinal fluid (CSF) with a white blood cell count of $3290 \times 10^{6} / \mathrm{L}$, with $88 \%$ being polymorphonuclear neutrophils (normal range 0 to $5 \times 10^{6} / \mathrm{L}$ ). The CSF glucose level was decreased at $1.5 \mathrm{mmol} / \mathrm{L}$ (normal range $2.8 \mathrm{mmol} / \mathrm{L}$ to $4.4 \mathrm{mmol} / \mathrm{L}$ ) and total CSF protein concentration was increased at $1.50 \mathrm{~g} / \mathrm{L}$ (normal range $0.15 \mathrm{~g} / \mathrm{L}$ to $0.45 \mathrm{~g} / \mathrm{L}$ ). Microscopy showed Gram-positive bacilli. CSF and blood cultures identified the organism as $L$ monocytogenes.

The patient was initially treated with intravenous ampicillin and gentamicin, and was then switched to intravenous ampicillin and trimethoprim-sulfamethoxazole, thereby completing a total of three weeks of antibiotic treatment. He recovered completely without any neurological sequelae.

His inflammatory bowel disease is currently in remission on $4 \mathrm{~g}$ of 5 -ASA and $2.5 \mathrm{mg} / \mathrm{kg} /$ day of azathioprine.

\section{DISCUSSION}

Adverse effects of infliximab therapy include infusion reactions, serum sickness-like disease and the development of autoantibodies (particularly antinuclear antibodies); these effects are rarely complicated by a lupus-like syndrome (3).

However, there has been increasing concern about infectious complications following infliximab infusions. Recent data from A Crohn's disease Clinical trial Evaluating infliximab in a New long term Treatment regimen (ACCENT I) (3) and the Mayo Clinic (5) in Rochester, Minnesota, USA, have shown that $32 \%$ and $8.2 \%$ of patients developed infections after infliximab infusion, respectively. Serious infections, including sepsis, occurred in approximately $4 \%$ of patients treated in both studies $(3,5)$, and there seemed to be no correlation between the number of infusions and the rate of infectious events $(3,5,9)$. When it was recognized that reactivation of tuberculosis could develop soon after treatment with infliximab, screening for latent tuberculous infection or active disease before therapy was advised (9). Several other opportunistic infections have been reported following infliximab infusion, including pneumocystosis, pulmonary aspergillosis, histoplasmosis, severe candida infections, coccidioidomycosis, cryptococcosis, cytomegalovirus, varicella-zoster virus and Epstein-Barr virus infections $(5,9-16)$.

Infections caused by $L$ monocytogenes complicating infliximab treatment for CD were first described in 2000 (17). The eight cases reported in the literature to date are summarized in Table 1. A review of the United States Food and Drug Administration's Adverse Event Reporting Program produced three CD patients on infliximab who developed listeria septicemia and/or meningitis (18), one of whom died. All patients were receiving concurrent immunosuppressive drugs, including a 17-year-old girl reported by Kamath et al (19). Two additional cases were mentioned in an addendum to the report by Slifman et al (18), but no further detail was provided. In addition, meningitis caused by $L$ monocytogenes has recently been reported in three patients with $C D$ treated with infliximab $(6,20,21)$, and the present patient constitutes the ninth reported case.

Listeria meningitis occurred in the present patient after the second infusion of infliximab while on azathioprine and corticosteroids. He received the drug four weeks instead of two weeks after the first infusion due to a scheduling error. As noted by others, the most serious infections after infliximab treatment occur after three or fewer infusions $(5,9,18)$, and almost all of the reported patients with inflammatory bowel disease were also concomitantly taking corticosteroids and azathioprine or 6-mercaptopurine $(17-20,22)$. Currently, there are no data on the incidence rate of listeriosis in CD. A comparison of the rate of $L$ monocytogenes infection between patients who 
received infliximab versus those who did not is therefore impossible because population-based data are lacking. The extent to which other immunomodulating drugs influence susceptibility to serious infections in patients on infliximab is not clear. In a recent study, Colombel et al (5) used a CochranMantel-Haenszel analysis to demonstrate that the use of combination treatment consisting of corticosteroids and azathioprine, 6-mercaptopurine or methotrexate may increase the risk significantly.

In contrast with $\mathrm{CD}$, there have been twice as many cases of rheumatoid arthritis reported in which anti-TNF- $\alpha$ treatment was complicated by serious listeria infections, including sepsis, meningitis and death (18,21-23). Data from the United States indeed suggest that the rate of $L$ monocytogenes infection in infliximab-treated rheumatoid patients (five of 82,000) may be higher than in CD patients (two of 104,500) who received this drug (18). This may be related to the greater use of methotrexate in rheumatoid arthritis, the different dose or dosing schedule of infliximab, or the higher median age of patients with rheumatoid disease. Infliximab-linked listeria infections have also been reported in patients with ulcerative colitis, psoriatic arthritis and juvenile rheumatoid arthritis $(18,24)$.

Infliximab reduces mucosal inflammation by several mechanisms of action (25). It binds and clears soluble TNF- $\alpha$, thereby neutralizing its proinflammatory effects. It also binds to cellbound TNF- $\alpha$ on macrophages and T cells, which interferes with direct cell-to-cell interactions and facilitates their destruction. Furthermore, in active CD, infliximab induces apoptosis of peripheral blood monocytes and leads to an increase in the number of apoptotic $\mathrm{T}$ lymphocytes in the lamina propria (25).

TNF- $\alpha$ plays a pivotal role in the pathogenesis of CD, and a marked increase of this cytokine is found in the intestinal mucosa of patients $(26,27)$.

Apart from its proinflammatory role, TNF- $\alpha$ also plays an important role in the defense against microbial infections.

The interaction between listeria infection and the host response is complex (28), but there is good evidence suggesting that TNF- $\alpha$ plays an important role in host defense against $L$ monocytogenes. Recent studies, for example, have shown that TNF- $\alpha$-deficient mice were highly susceptible to $L$ monocytogenes infection $(29,30)$. The presence of this cytokine and its type I receptor, p55, seems to be critical for resistance against primary infection by this intracellular pathogen (31).

It is therefore evident that the anti-TNF- $\alpha$ effects of infliximab are, on one hand, of great benefit to patients with CD but may, on the other hand, predispose them to serious infections such as listeriosis. This risk was addressed by the drug manufacturer by issuing a warning regarding the possible increased occurrence of opportunistic infections, including listeria (16). It is not clear whether infection originates from ingestion of contaminated food or from chronic fecal carriage in these immunocompromised patients. Indeed, the occurrence of infection shortly after the initiation of therapy with infliximab could be consistent with reactivation of latent infection (32). Therefore, recommendations to avoid foods such as soft cheeses and unpasteurized dairy products and to reheat (until steaming) processed meats such as hot dogs seem very reasonable in patients starting infliximab therapy $(19,23)$. Clinicians should be aware of this complication after infliximab infusions and should consider aggressive investigation and empirical antibiotic treatment in patients with new-onset central nervous system symptoms.

\section{REFERENCES}

1. Targan SR, Hanauer SB, van Deventer SJ, et al. A short-term study of chimeric monoclonal antibody cA2 to tumor necrosis factor alpha for Crohn's disease. Crohn's Disease cA2 Study Group. N Engl J Med 1997;337:1029-35.

2. Present DH, Rutgeerts P, Targan S, et al. Infliximab for the treatment of fistulas in patients with Crohn's disease. N Engl J Med 1999;340:1398-405.

3. Hanauer SB, Feagan BG, Lichtenstein GR, et al; ACCENT I Study Group. Maintenance infliximab for Crohn's disease: The ACCENT I randomised trial. Lancet 2002;359:1541-9.

4. Ricart E, Panaccione R, Loftus EV, Tremaine WJ, Sandborn WJ. Infliximab for Crohn's disease in clinical practice at the Mayo Clinic: The first 100 patients. Am J Gastroenterol 2001;96:722-9.

5. Colombel JF, Loftus EV Jr, Tremaine WJ, et al. The safety profile of infliximab in patients with Crohn's disease: The Mayo clinic experience in 500 patients. Gastroenterology 2004;126:19-31.

6. Ljung T, Karlen P, Schmidt D, et al. Infliximab in inflammatory bowel disease: Clinical outcome in a population based cohort from Stockholm County. Gut 2004;53:849-53.

7. Greenberg HB, Matsui SM, Holodniy M. Small intestine: Infections with common bacterial and viral pathogens. In: Yamada T, Alpers DH, Laine L, Owyang C, Powell DW, eds. Textbook of gastroenterology, 3rd edn. Philadelphia: Lippincott Williams \& Wilkins, 1999:1530-60.

8. Hamer DH, Gorbach SL. Infectious diarrhea and bacterial food poisoning. In: Feldman M, Friedman LS, Sleisenger MH, eds. Sleisenger and Fordtran's Gastrointestinal and Liver Disease, 7th edn. Philadelphia: WB Saunders Company, 2002:1864-1913.

9. Keane J, Gershon S, Wise RP, et al. Tuberculosis associated with infliximab, a tumor necrosis factor alpha-neutralizing agent. N Engl J Med 2001;345:1098-104.

10. Tai TL, O'Rourke KP, McWeeney M, Burke CM, Sheehan K, Barry M. Pneumocystis carinii pneumonia following a second infusion of infliximab. Rheumatology (Oxford) 2002;41:951-2.

11. Warris A, Bjorneklett A, Gaustad P. Invasive pulmonary aspergillosis associated with infliximab therapy. N Engl J Med 2001;344:1099-100.

12. Keenan GF, Schaible TF, Boscia JA. Invasive pulmonary aspergillosis associated with infliximab therapy (reply). N Engl J Med 2001;344:1100.

13. Lee JH, Slifman NR, Gershon SK, et al. Life-threatening histoplasmosis complicating immunotherapy with tumor necrosis factor alpha antagonists infliximab and etanercept. Arthritis Rheum 2002;46:2565-70.

14. Nakelchik M, Mangino JE. Reactivation of histoplasmosis after treatment with infliximab. Am J Med 2002;112:78.

15. Diamanti A, Papadatou B, Knafelz D, Gambarara M, Ferretti F, Castro M. Complications of infliximab therapy in children and adolescents affected by Crohn's disease. Am J Gastroenterol 2003;98:2812-3.

16. Remicade (infliximab) for IV injection. Package Insert. Pennsylvania: Centocor Inc, 2003. <http://www.remicade.com/ pdf/PPI.pdf $>$ (Version current at September 29, 2005).

17. Morelli J, Wilson FA. Does administration of infliximab increase susceptibility to listeriosis? Am J Gastroenterol 2000;95:841-2.

18. Slifman NR, Gershon SK, Lee JH, Edwards ET, Braun MM. Listeria monocytogenes infection as a complication of treatment with tumor necrosis factor alpha-neutralizing agents. Arthritis Rheum 2003;48:319-24.

19. Kamath BM, Mamula P, Baldassano RN, Markowitz JE. Listeria meningitis after treatment with infliximab. J Pediatr Gastroenterol Nutr 2002;34:410-2.

20. Joosten AA, van Olffen GH, Hageman G. [Meningitis due to Listeria monocytogenes as a complication of infliximab therapy.] Ned Tijdschr Geneeskd 2003;147:1470-2.

21. Tweezer-Zaks N, Shiloach E, Spivak A, Rapoport M, Novis B, Langevitz P. Listeria monocytogenes sepsis in patients treated with anti-tumor necrosis factor-alpha. Isr Med Assoc J 2003;5:829-30.

22. Bowie VL, Snella KA, Gopalachar AS, Bharadwaj P. Listeria meningitis associated with infliximab. Ann Pharmacother 2004;38:58-61. 
23. Gluck T, Linde HJ, Scholmerich J, Muller-Ladner U, Fiehn C, Bohland P. Anti-tumor necrosis factor therapy and Listeria monocytogenes infection: Report of two cases. Arthritis Rheum 2002;46:2255-7.

24. Aparicio AG, Munoz-Fernandez S, Bonilla G, Miralles A, Cerdeno V, Martin-Mola E. Report of an additional case of antitumor necrosis factor therapy and Listeria monocytogenes infection: Comment on the letter by Gluck et al. Arthritis Rheum 2003;48:1764-5.

25. van Deventer SJ. Review article: Targeting TNF alpha as a key cytokine in the inflammatory processes of Crohn's disease - the mechanisms of action of infliximab. Aliment Pharmacol Ther 1999;13(Suppl 4):3-8.

26. Murch SH, Braegger CP, Walker-Smith JA, MacDonald TT. Location of tumour necrosis factor alpha by immunohistochemistry in chronic inflammatory bowel disease. Gut 1993;34:1705-9.

27. Cappello M, Keshav S, Prince C, Jewell DP, Gordon S. Detection of mRNAs for macrophage products in inflammatory bowel disease by in situ hybridisation. Gut 1992;33:1214-9.

28. Edelson BT, Unanue ER. Immunity to Listeria infection. Curr Opin Immunol 2000;12:425-31.

29. Mizuki M, Nakane A, Sekikawa K, Tagawa YI, Iwakura Y. Comparison of host resistance to primary and secondary Listeria monocytogenes infections in mice by intranasal and intravenous routes. Infect Immun 2002;70:4805-11.

30. Dinarello CA. Anti-cytokine therapeutics and infections. Vaccine 2003;21(Suppl 2):S24-34.

31. White DW, Badovinac VP, Fan X, Harty JT. Adaptive immunity against Listeria monocytogenes in the absence of type I tumor necrosis factor receptor p55. Infect Immun 2000;68:4470-6.

32. Wallis RS, Broder MS, Wong JY, Hanson ME, Beenhouwer DO. Granulomatous infectious diseases associated with tumor necrosis factor antagonists. Clin Infect Dis 2004;38:1261-5. 


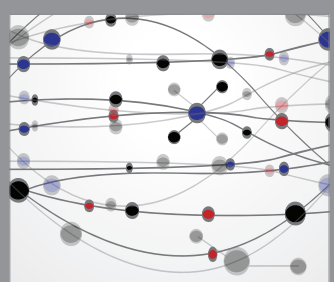

The Scientific World Journal
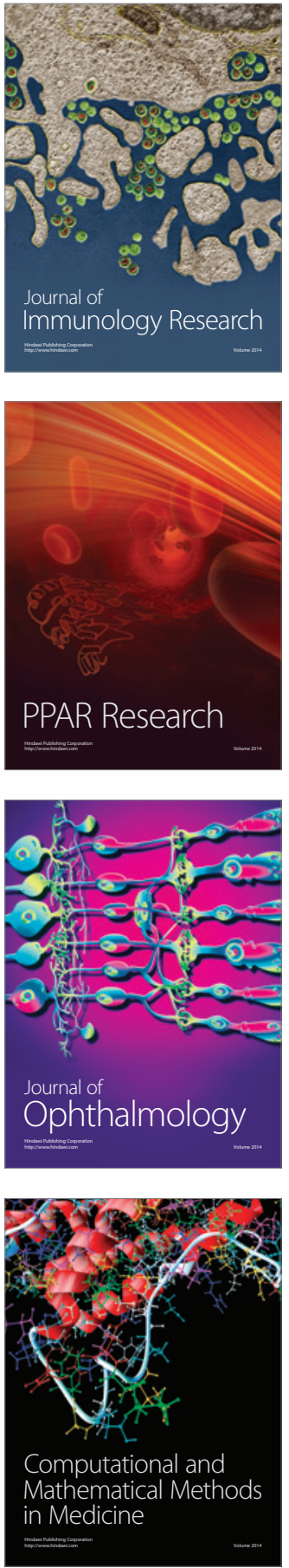

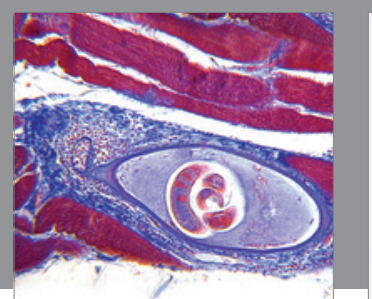

Gastroenterology Research and Practice

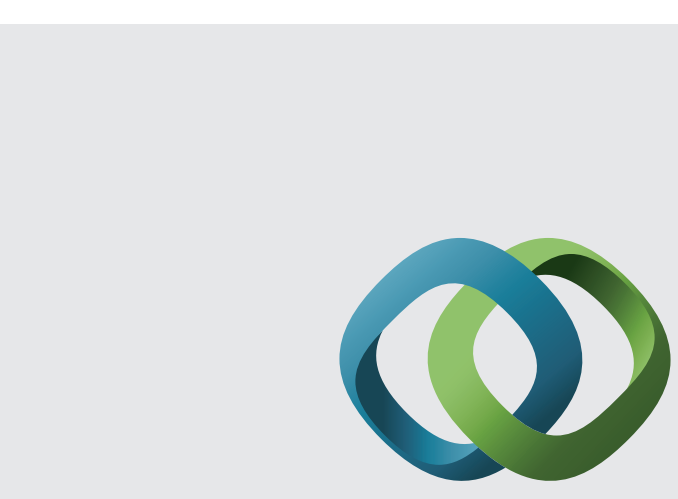

\section{Hindawi}

Submit your manuscripts at

http://www.hindawi.com
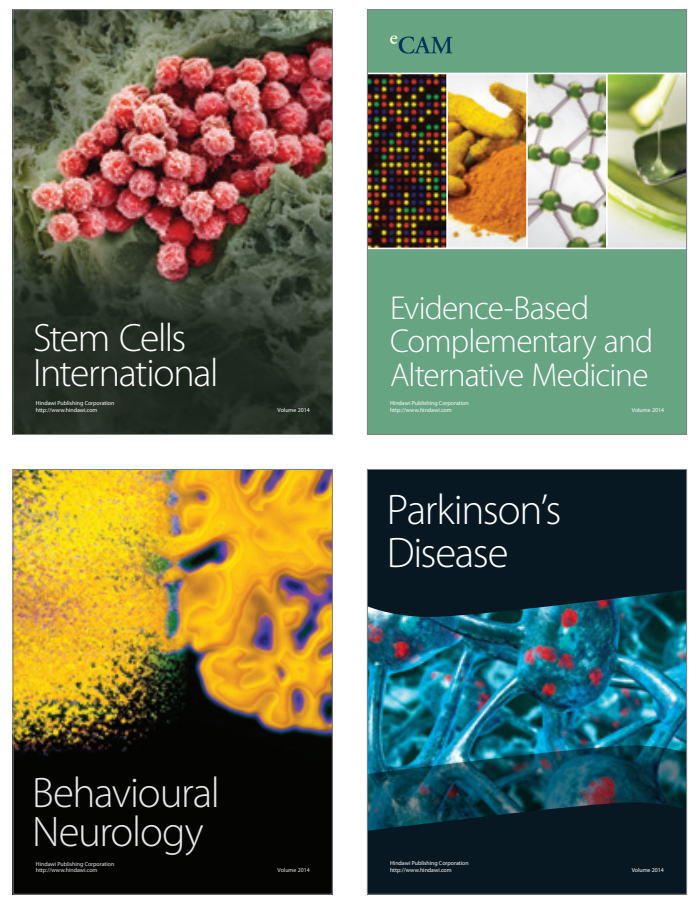
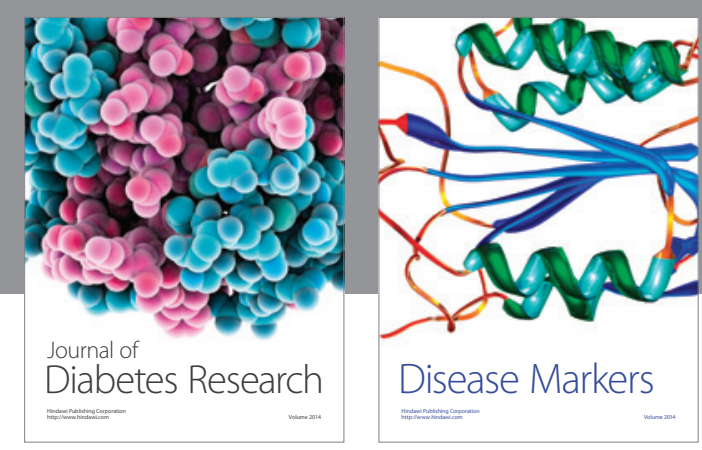

Disease Markers
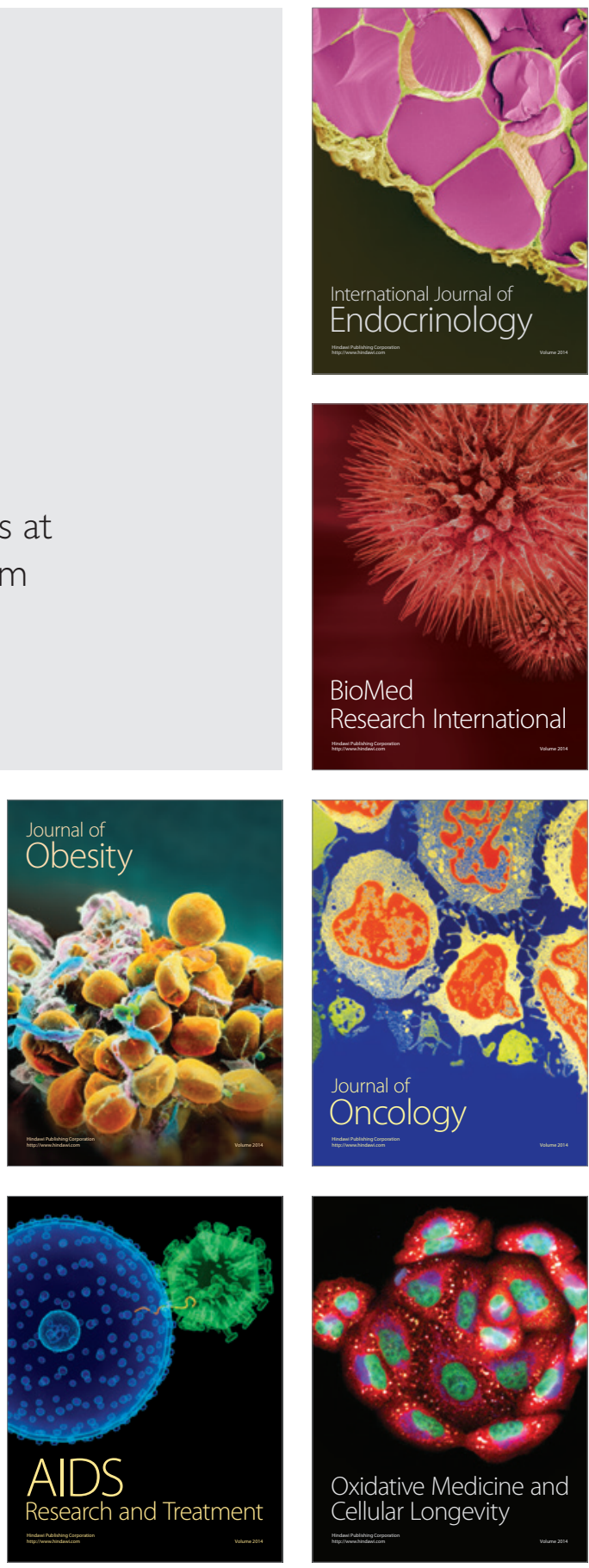